\title{
Ocena predyktorów kognitywnego rozwoju moralnego przyszłych menedżerów przy wykorzystaniu teorii dwuaspektowej
}

\begin{abstract}
Streszczenie
Przeprowadzono badania wśród studentów zarządzania pochodzących z czterech krajów. Przy wykorzystaniu teorii CMD Kohlberga i teorii dwuaspektowej Linda ustalono, że wzajemne oddziaływanie dwóch czynników, mianowicie kraju pochodzenia i poziomu religijności, ma istotny związek z rozwojem moralnym. W przypadku studentów z Polski i Ukrainy osoby deklarujące wyższą religijność są na wyższym etapie rozwoju moralnego, w przypadku studentów z Bułgarii i Stanów Zjednoczonych relacja jest odwrotna. Ustalono, że wyniki badań zależą istotnie od rodzaju wykorzystanego dylematu moralnego.

Słowa kluczowe: moralność w biznesie, kognitywny rozwój moralny, teoria Kohlberga, teoria dwuaspektowa Linda
\end{abstract}

Wprowadzenie

W 2016 roku amerykańska organizacja pozarządowa Graduate Management Admission Council (GMAC), skupiająca przodujące szkoły zarządzania

Prof. dr hab. Marek Pawlak, profesor w Katedrze Zarządzania Przedsiębiorstwem w Instytucie Dziennikarstwa i Zarządzania na Wydziale Nauk Społecznych Katolickiego Uniwersytetu Lubelskiego Jana Pawła II; e-mail: marek.pawlak@kul.pl; ORCID: 0000-0002-5620-370X. 
ze Stanów Zjednoczonych, Kanady, Azji i Europy, opublikowała swój coroczny raport, w którym m.in. znalazły się wyniki badań przeprowadzonych wśród pracodawców. Zapytano ich, jakie cechy i umiejętności są najważniejsze przy ocenie absolwentów studiów zarządzania (MBA) jako potencjalnych pracowników ich przedsiębiorstw. Spośród 10 badanych cech na pierwszym miejscu znalazła się zdolność kandydata do dopasowania się do kultury organizacji, dalej była zdolność do pracy w zespole i zdolność do wywierania wpływu. Badania przeprowadzono z podziałem na osiem branż i na miejscach od czwartego do siódmego w zależności od branży uplasowała się „wysoka etyka biznesu”, której będą poświęcone rozważania zawarte w tym artykule.

Podobne wyniki badań GMAC opublikowała także w 2005 roku i wynikało z nich, że przedsiębiorstwa poszukują absolwentów studiów o wysokim poziomie rozwoju moralnego. Firmy chcą zwiększyć swoje szanse na zatrudnianie osób etycznych poprzez praktyki rekrutacyjne, badania przesiewowe i ocenę potencjalnych pracowników (Traiser, Eighmy, 2011).

To że działania biznesowe powinny być etyczne, znalazło swoje potwierdzenie także w wynikach wielu innych badań. Przykładowo P. Maria Joseph Christie i współpracownicy (Christie i in., 2003) prowadzili badania opinii menedżerów w Stanach Zjednoczonych, Indiach, Korei, na podstawie których stwierdzili, że większość z respondentów (99\% Amerykanów, 96\% Hindusów i 84\% Koreańczyków) uważa, iż należy się zachowywać etycznie, prowadząc swoje firmy, aby zagwarantować długoterminowy sukces i rentowność. Większość ankietowanych (96\% Amerykanów, 71\% Hindusów i 38\% Koreańczyków) zgodziła się ze stwierdzeniem, że „bycie etycznym i bycie rentownym nie wykluczają się wzajemnie”. Menedżerowie wierzą, że można osiągać zyski, będąc jednocześnie etycznym. Natomiast, jak wskazują liczne skandale odnotowane na całym świecie w ostatnich latach, zachowanie nieetyczne jest kosztowne dla firm, ich pracowników i inwestorów (Conroy, Emerson, 2004). Niektórzy badacze sugerują, że etyczne inicjatywy w takich korporacjach, jak General Dynamics i General Electric okazały się opłacalne (Izzo, 2000).

\section{Kognitywny rozwój moralny}

Etyka jest dyscypliną, która zajmuje się rozpatrzeniem, co jest dobre, a co złe, a także moralnymi powinnościami i obowiązkami (Carroll, Buchholz, 2009). Etyka jest systematycznym podejściem do osądów moralnych opartym na rozsądku, analizie, syntezie i refleksji; etyka biznesu stanowi zastosowanie zasad etycznych do kwestii, które pojawiają się w prowadzeniu działalności gospodarczej - odnosi się do sytuacji, w których osoby fizyczne znajdują się w sytuacji organizacyjnej 
i działają jako (odpowiedzialni) agenci firmy i jej właścicieli (Christie i in., 2003). Wielu autorów używa pojęć „etyka” i „moralność” zamiennie, tak też są one traktowane w tym artykule.

Etapy etycznego podejmowania decyzji

Według Jamesa Resta (1986) w procesie podejmowania decyzji przy uwzględnieniu kwestii etycznych można wyróżnić cztery następujące po sobie komponenty (etapy; rysunek 1).

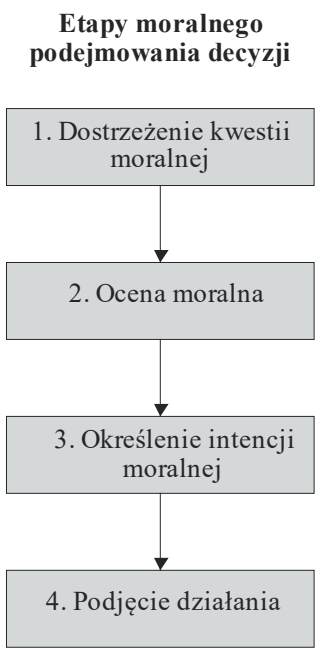

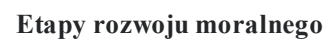
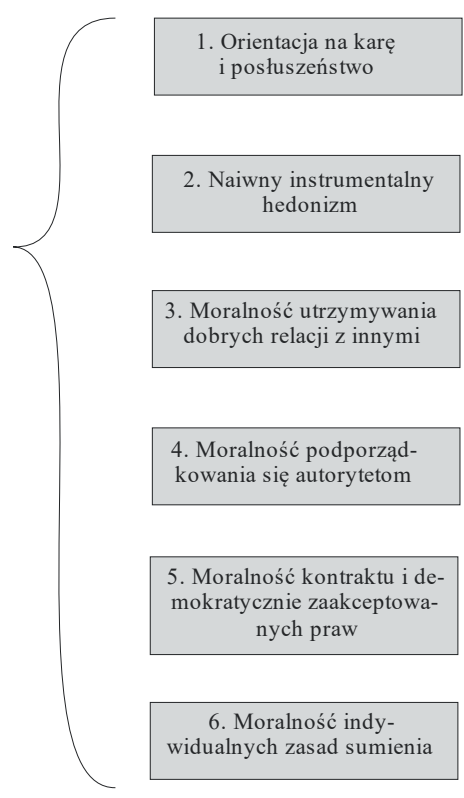
2. Naiwny instrumentalny hedonizm

i posłuszeństwo

$$
\begin{aligned}
& \text { 3. Moralność utrzymywania } \\
& \text { dobrych relacji z innymi }
\end{aligned}
$$

4. Moralność podporządkowania się autorytetom

5. Moralność kontraktu i demokratycznie zaakceptowanych praw

6. Moralność indywidualnych zasad sumienia
Poziom

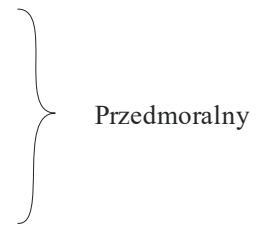

Moralność konwencjonalnej roli - konformizmu

Moralność samodzielnie akceptowanych zasad moralnych

Rysunek 1. Etapy moralnego podejmowania decyzji i etapy rozwoju moralnego Źródło: opracowanie własne.

W komponencie pierwszym następuje interpretowanie sytuacji z punktu widzenia możliwych działań, a także skutków tych działań dla siebie i dla innych (Trevino, 1992), osoba rozpoznaje, że istnieje kwestia moralna (Foo i in., 1997). Rozpoznanie to zależy od wrażliwości etycznej, czyli zdolności dostrzegania, że sytuacja ma komponent etyczny. Ludzie muszą być w stanie dostrzec, iż sytuacja ma komponenty moralne (Swenson-Lepper, 2005). Osoba staje się świadoma określonej sytuacji i interpretuje ją w kategoriach możliwych działań, które prowadzą do percepcji 
etycznego konfliktu. Innymi słowy - osoba dostrzega, że mogłaby coś zrobić, co wpływa na interesy, pomyślność lub oczekiwania innych ludzi.

W komponencie drugim dochodzi do jasnej oceny moralnej (Foo i in., 1997), następuje osądzenie. Osoba określa wariant działania, który jest odpowiedni z moralnego punktu widzenia. Według Resta $(1986$, s. 3) „praca badawcza polega tu na określeniu (zrozumieniu), w jaki sposób ludzie dokonują tych osądów (jak działa intuicja moralna), w celu zrozumienia różnic w osądach i w celu zrozumienia pewności ludzi odnośnie tych osądów, nawet odnośnie niezmiernie skomplikowanych kwestii". W tym obszarze znajduje się cały paradygmat kognitywnego rozwoju osądów moralnych. Bazą do badania tego paradygmatu jest określenie, jak ludzie dochodzą do różnych odczuć na temat sprawiedliwości (zwykle określanych w kategoriach „etapów” moralnego osądzania (oceniania)). Teoria kognitywnego rozwoju moralnego (ang. Cognitive Moral Development - CMD) zajmuje się właśnie tym komponentem całego procesu (Trevino, 1992).

W komponencie trzecim następuje określenie priorytetu tego, co jest moralnie właściwe, w relacji do innych konfliktowych wariantów działań (Foo i in., 1997; Trevino, 1992), czyli określa się intencję moralną (Schwepker, 1999). Aby tego dokonać, trzeba porównać swoje wartości moralne z wartościami innych osób (Swenson-Lepper, 2005). Na przykład osoba może wysoko cenić rozwój kariery osobistej, co może być w konflikcie z wyborem alternatywy moralnej, takiej jak publiczne informowanie o nadużyciach.

W komponencie czwartym następuje zademonstrowanie swego zaangażowania i umiejętności, aby zgodnie z intencją zachowywać się moralne (Trevino, 1992), czyli osoba zachowuje się w sposób zgodny z wcześniejszą intencją (Foo i in., 1997; Schwepker, 1999; Swenson-Lepper, 2005). Osoba musi wytrzymać to, co Rest określa mianem „wola fatygowania się i opadania z sił” oraz pokonać trudności, aby zgodnie z intencją zachować się w sposób moralny (Foo i in., 1997).

Człowiekowi może się nie powieść zrealizowanie któregoś z tych etapów i tym samym nie uda mu się działać etycznie (Swenson-Lepper, 2005).

Ocena moralna

Ocena moralna, czyli drugi komponent procesu, leży u podstaw większości modeli etycznego podejmowania decyzji, także w zarządzaniu i marketingu. Większość tradycyjnych badań oceny moralnej (tzn. określenia, czy coś jest dobre, czy złe) dotyczyła raczej wartości moralnych, a zatem zasad, jakimi ludzie kierują się w życiu przy podejmowaniu decyzji. Modele etycznego podejmowania decyzji zakładają, że oceny moralne bazują na zasadach moralnych mających swoje uzasadnienie w filozofii moralnej (tzn. filozofii wyjaśniającej, w jaki sposób ludzie określają, co jest dobre, a co złe). Jednak dopiero Linda Klebe Trevino (1986) zasugerowała, 
że nie system wartości, ale cecha człowieka określona mianem „kognitywnego rozwoju moralnego" (CMD) wpływa na to, jak człowiek ocenia, co jest dobre, a co złe (Schwepker, 1999).

Kognitywny rozwój moralny

Należy podkreślić, że CMD odnosi się do uzasadnień, jakich używa osoba, aby wytłumaczyć osądy moralne, a nie do samych decyzji. Dlatego pytanie dotyczy tego, jak ludzie dochodzą do uzasadnień, co jest moralnie właściwe, a co nie. Zatem celem CMD jest zrozumienie i przewidywanie moralnego zachowania (Foo i in., 1997).

Kognitywny rozwój moralny jest krytycznym elementem w fazie oceny etycznego podejmowania decyzji. Według teorii CMD podejmowanie przez człowieka decyzji staje się coraz bardziej kompleksowe i wyszukane wraz z jego rozwojem moralnym. Model CMD stworzony przez Lawrence’a Kohlberga sugeruje, że ludzie mogą reagować rozmaicie na dany dylemat moralny, ponieważ są na różnych etapach swojego rozwoju moralnego (Schwepker, 1999). Rozwój moralny człowieka odzwierciedla, w jaki sposób w jego umyśle zorganizowane są moralne preferencje (Roberts, Wasieleski, 2012).

Za twórcę teorii CMD uważany jest Kohlberg. W 1963 roku w swojej wczesnej publikacji na ten temat w sposób następujący określił typy i poziomy rozwoju moralnego, przy czym używane na początku pojęcie „typy” rozwoju moralnego zostały później określone mianem „etapów” rozwoju moralnego.

Poziom I. Przedmoralny:

Typ 1. Orientacja na karę i posłuszeństwo.

Typ 2. Naiwny instrumentalny hedonizm.

Poziom II. Moralność konwencjonalnej roli - konformizmu:

Typ 3. Moralność dobrego chłopca, utrzymywania dobrych relacji, aprobaty innych.

Typ 4. Moralność podporządkowania się autorytetom.

Poziom III. Moralność samodzielnie akceptowanych zasad moralnych:

Typ 5. Moralność kontraktu i demokratycznie zaakceptowanych praw.

Typ 6. Moralność indywidualnych zasad sumienia.

Opisów poszczególnych typów (etapów) jest bardzo wiele i w prawie każdej publikacji na ten temat są nieco inne sformułowania.

Etap pierwszy - orientacja na karę i posłuszeństwo. Osoby będące na tym etapie rozwoju moralnego są nastawione na unikanie łamania reguł, które są wymuszane przez system kar. Zasady zostają określane przez władzę zwierzchnią. O tym, czy działanie jest dobre, czy złe, decydują jego fizyczne konsekwencje niezależnie od ludzkiego znaczenia lub wartości tych konsekwencji. Chodzi tu także 
o niekwestionowanie szacunku do władzy. Osoby, które są na pierwszym etapie rozwoju moralnego, troszczą się tylko o siebie. Przestrzegają prawa i podporządkowują się władzy jedynie po to, aby uniknąć kar (Kracher, Marble, 2008).

Etap drugi - orientacja instrumentalno-relatywistyczna (naiwny instrumentalny hedonizm). Przejawia się w realizowaniu własnych interesów i pozwoleniu innym, aby robili to samo. Przestrzega się zasad tylko wtedy, gdy jest to we własnym interesie (Fraedrich, Thorne, Ferrell, 1994). Właściwe działanie polega na tym, co instrumentalnie spełnia własne potrzeby, a czasem także potrzeby innych. Relacje międzyludzkie są postrzegane w kategoriach podobnych do rynkowych. Obecne są tu elementy sprawiedliwości, wzajemności i równego podziału, ale zawsze są interpretowane w sposób fizyczny, pragmatyczny. Wzajemność jest kwestią interesów. "Jeśli zrobisz dla mnie coś, czego ja dla siebie nie mogę zrobić, to ja zrobię dla ciebie coś, czego ty dla siebie nie możesz zrobić". Wzajemność nie wynika z lojalności, wdzięczności czy sprawiedliwości (Kohlberg, Hersh, 1977).

Etap trzeci - orientacja interpersonalna. Ludzie, którzy są na tym etapie rozwoju, wykazują się dobrym stereotypowym zachowaniem. Wypełniają to, co jest oczekiwane od osoby w danej roli. Przypisuje się wagę do zaufania, lojalności, wdzięczności (Fraedrich i in., 1994). Stosowana jest empatia. Dobre zachowanie to takie, które podoba się lub pomaga innym i jest przez nich akceptowane. Istnieje tu wiele konformizmu ze stereotypowymi obrazami tego, co jest zachowaniem większości lub zachowaniem „naturalnym”. Zachowanie jest często oceniane przez intencję - „on chciał zrobić dobrze”. Można zdobyć aprobatę, będąc „miłym” (Kohlberg, Hersh, 1977). Na tym etapie znaczenie mają relacje i role interpersonalne. Osoby przejawiające ten typ moralności już nie myślą w kategoriach indywidualnych korzyści, ale chcą uczestniczyć w długotrwałych wzajemnych relacjach. Są zainteresowane byciem godnym zaufania (wiarygodnym) i lojalnym. Przestrzegają prawo, aby być dobrym i pasować do innych (Kracher, Marble, 2008).

Etap czwarty - moralność podporządkowania się autorytetom, orientacja na "prawo i porządek”. Ludzie, którzy są na tym etapie rozwoju, zaczynają wnosić własny wkład na rzecz społeczeństwa, grupy lub instytucji. Wypełniają obowiązki, z którymi się zgadzają. Utrzymywany jest punkt widzenia systemu społecznego i dąży się do jego podtrzymania (Fraedrich i in., 1994). Występuje tu ukierunkowanie na autorytet, ustalone reguły i utrzymanie obowiązujących zasad. Właściwe zachowanie polega na wykonywaniu obowiązków, okazaniu szacunku autorytetom i utrzymywaniu danego porządku społecznego dla niego samego (Kohlberg, Hersh, 1977). Osoby, które są na etapie czwartym, nadal postrzegają siebie jako członków grupy, aczkolwiek na tym etapie grupa rozszerza się do postaci określonego systemu społecznego. Ludzie dostrzegają wartość swoich ról społecznych, rozumieją znaczenie przestrzegania prawa $\mathrm{w}$ celu podtrzymywania porządku 
społecznego. Reguły moralne zależą jednak od grupy społecznej (Kracher, Marble, 2008).

Etap piąty - moralność kontraktu i demokratycznie zaakceptowanych praw. Na tym etapie rozwoju reguły są przestrzegane, ponieważ są one efektem kontraktu społecznego. Przestrzeganie prawa i obowiązków bazuje na racjonalnych determinantach ogólnej użyteczności (Fraedrich i in., 1994). Właściwe działanie definiuje się w kategoriach ogólnego, powszechnie obowiązującego prawa i standardów, które zostały krytycznie zbadane i uzgodnione przez całe społeczeństwo. Istnieje wyraźna świadomość relatywizmu i opinii wartości osobistych oraz odpowiedni nacisk na proceduralne zasady osiągania konsensusu. Prawem jest to, co uzgodniono konstytucyjnie i demokratycznie. Rezultatem staje się nacisk na "prawny punkt widzenia”, ale $\mathrm{z}$ naciskiem na możliwość zmiany prawa w kategoriach racjonalnego rozważenia użyteczności społecznej (zamiast zamrażania go w kategoriach „prawa i porządku” etapu czwartego; Kohlberg, Hersh, 1977). Osoby, które są na etapie piątym, zaczynają myśleć w kategoriach szerszych niż ich własny system społeczny, i rozszerzają swoje zasady moralne. Promują prawa indywidualne, ale nie tylko dlatego, że ich własny system społeczny je popiera. Na tym etapie ludzie mogą bronić praw indywidualnych poprzez ideę kontraktu społecznego, który zapewnia ogólnospołeczny pożytek (Kracher, Marble, 2008).

Etap szósty - orientacja na uniwersalne zasady etyczne. Na tym etapie poprawność określana jest na podstawie zgodności z wybranymi przez siebie zasadami etycznymi, odwołującymi się do logicznej wszechstronności, uniwersalności i spójności. Prawo i obowiązki społeczne są uzasadnione jedynie dlatego, że opierają się na tych zasadach. Jednostka respektuje godność wszystkich istot ludzkich na bazie własnych decyzji, ma osobisty wkład do (obowiązujących) poglądów (Fraedrich i in., 1994). Zasady te są abstrakcyjne i dotyczą kwestii etycznych (złota zasada, kategoryczny imperatyw); nie są to konkretne zasady moralne, takie jak np. Dekalog. $\mathrm{W}$ istocie są to uniwersalne zasady sprawiedliwości, wzajemności i równości praw oraz poszanowania godności człowieka jako osoby ludzkiej (Kohlberg, Hersh, 1977). Osoby na etapie szóstym mają całkowicie osobiste poglądy na temat sprawiedliwości. Zasady moralne są uniwersalne, a zatem oderwane od jakiegokolwiek określonego systemu społecznego. Osoby na tym etapie żyją według własnych zasad sprawiedliwości, dlatego że takie postępowanie jest dobre (Kracher, Marble, 2008), wykorzystują samodzielnie akceptowane pryncypia prawości i sprawiedliwości, aby wyjaśnić swoje osądy moralne (Kracher, Chatterjee, Lundquist, 2002).

Zaproponowane przez Kohlberga etapy rozwoju moralnego mają trzy podstawowe cechy (Foo i in., 1997): (1) osoby są konsekwentne w różnych sytuacjach odnośnie do poziomu moralnego wnioskowania (tzn. dążą do rozumowania na jednym (określonym) etapie bez względu na dylemat moralny); (2) niezależnie od 
kultury osoby nie przeskakują etapów i zawsze przechodzą do wyższego po serii etapów niższych; (3) etapy są ", hierarchicznymi całościami”, efektem integracji (tzn. myślenie na wyższym etapie zawiera lub obejmuje myślenie na etapach niższych).

Etapy wyższe są lepsze niż niższe

Teoria Kohlberga zakłada, że procesy wnioskowania są rozwojowe w swojej naturze i że człowiek rozwija się, przechodząc przez kolejne etapy moralnego wnioskowania (Green, Weber, 1997). Zatem teoria CMD koncentruje się na progresywnym sposobie, w jaki osoba nabywa w miarę upływu czasu coraz bardziej odpowiednie zrozumienie natury moralnych zobowiązań w kompleksowych systemach społecznych (Goolsby, Hunt, 1992). Kohlberg (1973) twierdzi, że wyższe etapy prowadzą do bardziej adekwatnych rozwiązań problemów moralnych, ponieważ lepiej spełniają one formalne kryteria sprawiedliwości. Ponadto, jego zdaniem, sama wiedza jest motywującą. Spójność w myśleniu jest stymulującą lub wiążącą cechą, która popycha człowieka do działania w zgodzie z jego własnymi osądami (Arnold, 2000).

Model Kohlberga podkreśla kognitywny lub związany z rozumowaniem aspekt moralnego podejmowania decyzji. Dotyczy on kwestii, w jaki sposób kognitywny proces moralnego podejmowania decyzji staje się coraz bardziej kompleksowy i zaawansowany w miarę rozwoju człowieka. Nacisk jest tu położony raczej na kognitywny proces podejmowania decyzji, na argumenty, jakich człowiek używa dla uzasadnienia wyborów moralnych, a nie na samą decyzję (Trevino, 1986).

Teoria CMD dowodzi, że w miarę jak człowiek się rozwija, nabywa jednocześnie coraz więcej perspektyw i technik, które może wykorzystać w swoich relacjach $z$ otoczeniem. W rezultacie bieżący poziom moralnego rozumowania (argumentacji) zawiera techniki rozwiązywania problemów nauczone w poprzednich fazach. Dlatego też człowiek postrzega kwestię etyczną, ocenia ją i zachowuje się w zgodzie z dominującą społeczno-moralną perspektywą, ukształtowaną poprzez doświadczenie, edukację i rozwój fizyczny (Weber, Wasieleski, 2001).

Poziom rozumowania staje się coraz bardziej kompleksowy na każdym z hierarchicznych etapów i osoby używają coraz bardziej złożonego procesu podejmowania decyzji dla ustalania priorytetów i tego, co jest słuszne. Przesuwanie się (postęp) w hierarchii etapów odzwierciedla osiągnięty poziom rozwoju moralnego. Im większy postęp, tym wyższy osiągnięty poziom rozwoju moralnego i wyższy poziom umiejętności pryncypialnego podejmowania decyzji (Everett, Thorne, Danehower, 1996). Zasadniczo model CMD zakłada, że nastawienia do kwestii moralnych są różne na każdym z etapów i że te nastawienia kierują rzeczywistymi zachowaniami oraz działaniami człowieka. Zatem np. osoby, które są na etapie szóstym, 
demonstrują zdolność argumentowania na temat dylematów moralnych bardziej efektywnie niż osoby na etapach od pierwszego do piątego (Fraedrich i in., 1994).

Kohlberg uważał, że osądy na wyższym etapie są obiektywnie „lepsze” i dlatego bardziej pożądane niż osądy na etapie niższym, zarówno w kryteriach kognitywnych, jak i moralnych. Z punktu widzenia kryteriów kognitywnych twierdził, że osądy na etapie wyższym są bardziej kompleksowe w sensie kognitywnym (bardziej zróżnicowane), a także bardziej inkluzywne w sensie kognitywnym (zawierają osądy etapów niższych). W aspekcie kryteriów moralnych sądził, że osądy na etapie piątym „są bardziej zbliżone do kryteriów formalnych odróżniających osądy moralne od niemoralnych". Kryteria te zostały opracowane w ramach tradycji formalnej filozofii moralnej pochodzącej od Immanuela Kanta (Trevino, 1992).

W opinii Kohlberg rozwój moralny następuje zawsze w kolejnych etapach na bazie rozwoju kognitywnego. W miarę jak osoba „dojrzewa” moralnie, przesuwa się na wyższe szczeble kognitywnego rozwoju moralnego (Izzo, 2000). Kohlberg argumentował także, że zrozumienie moralnego wnioskowania jest rozwojowe, progresywne i kumulacyjne. Przykładowo osoba, która rozumie uniwersalne pryncypialne wnioskowanie na etapie szóstym, rozumie także etapy niższe (Izzo, 2000).

\section{Ograniczenia modelu Kohlberga}

Według modelu etapów etycznego podejmowania decyzji ludzie najpierw dochodzą do tego, co jest odpowiednie. Następnie decydują, czy są odpowiedzialni za implementację moralnego kierunku działania. W końcu, jeśli uznają, że są odpowiedzialni, próbują zebrać potrzebne środki, aby wybrany kierunek zrealizować (Krebs, Denton, 2005). Jednak ograniczeniem modelu Kohlberga jest to, że oceny moralnego wnioskowania odnoszą się jedynie do sfery kognitywnej - jak ludzie myślą o moralnych dylematach, a nie dotyczą działania - co ludzie rzeczywiście by zrobili w określonej sytuacji decyzyjnej (Trevino, 1986).

Wyniki badań Trevino (1986) wskazują, że jest umiarkowana relacja między myśleniem i działaniem. Zatem moralne osądy są koniecznym, ale niewystraczającym warunkiem moralnego zachowania, takiego jak: uczciwość, altruizm, odporność na pokusy.

Jednak Kohlberg i Daniel Candee (1984) starali się rozszerzyć wcześniejszy model, łącząc moralne osądy z moralnym zachowaniem, bazując na założeniu, że im bardziej dojrzałe jest zrozumienie, dlaczego wybór moralny jest odpowiedni, tym większe prawdopodobieństwo, że osoba będzie się zachowywała odpowiednio (Krebs, Danton, 2005).

Pomimo sceptycyzmu innych Kohlberg (1973) argumentował, że poznanie i działanie powinny być powiązane z powodu dążenia jednostki do osiągnięcia harmonii pomiędzy myśleniem i działaniem. Zatem uważał on, iż wyższe 
poziomy CMD powinny być powiązane z bardziej etycznymi zachowaniami. Jednak, jak pisze Trevino (1992), badania empiryczne dotyczące relacji pomiędzy moralnym wnioskowaniem i zachowaniem wskazują na istnienie między nimi umiarkowanej zależności.

Decyzje biznesowe

Wielu badaczy, m.in. Jerry R. Goolsby i Shelby D. Hunt (1992) oraz Trevino (1992), wskazywało na to, iż koncepcja kognitywnego rozwoju moralnego zaczerpnięta z dyscypliny psychologii może być użyteczna w zrozumieniu procesów etycznego wnioskowania w biznesie (Fraedrich i in., 1994). Trevino (1992) zaleca stosowanie CMD jako metody na zrozumienie, jak pracownicy myślą o dylematach etycznych w swoim środowisku pracy.

Przykładowo George Izzo (2000), na podstawie przeprowadzonych przez siebie badań, stwierdził, że w przypadku decyzji biznesowych, mających wydźwięk moralny, sprzedawcy ze słabo rozwiniętymi możliwościami kognitywnego wnioskowania (tzn. będący na niższych etapach rozwoju moralnego) nie byliby w stanie rozpoznać wszystkich ewentualnych możliwości lub ocenić prawa wszystkich zainteresowanych. Stąd w przypadku, gdy trzy różne osoby analizują pozornie ten sam dylemat moralny, mogą podać trzy różne działania moralne, bazując na różnych poziomach moralnego wnioskowania (Izzo, 2000).

Ponadto zrozumienie, jak różne osoby różnie podchodzą i stawiają czoło (pozornie) takim samym sytuacjom etycznym, ma ważne implikacje dla menedżerów przedsiębiorstw. Zatem wykorzystanie miar CMD do oceny zdolności moralnego wnioskowania pracowników może pomóc menedżerom nie tylko zrozumieć te różnice, ale także pomóc ustalić, jak wnioskować efektywnie, gdy pojawi się moralny dylemat (Izzo, 2000).

\section{Dylematy moralne (testy oceny rozwoju moralnego)}

Do badania etapów rozwoju moralnego używane są zazwyczaj dylematy moralne, czyli hipotetyczne sytuacje decyzyjne, których rozstrzygnięcie pociąga za sobą uwzględnienie kwestii moralnych. Każdy człowiek, rozpatrując dylemat moralny, myśli w możliwy do zidentyfikowania sposób. Sposób ten odzwierciedla specyficzny charakter moralnego wnioskowania, który umożliwia poklasyfikowanie ludzi do określonego etapu rozwoju moralnego (Foo i in., 1997).

W pierwszych badaniach prowadzonych przez Kohlberga i jego współpracowników (1963) uczestnikom prezentowano trzy opisy sytuacji składające się z moralnych dylematów. Każda sytuacja zawierała konflikt wartości i służyła testowaniu 
sposobu moralnego wnioskowania uczestnika badań. Badanym zadawane były ustnie otwarte pytania sprawdzające i także odpowiedzi były ustne. Umożliwiano respondentom i zachęcano ich, aby wyjaśniali swoje odpowiedzi, dostarczając bogaty i szczegółowy zakres informacji. Wywiad był ustrukturalizowany w celu określenia procesu wnioskowania, który leży u podstaw tego, co każdy uczestnik czuje, że powinien zrobić w każdej z trzech sytuacji etycznych (Weber, Wasieleski, 2001).

W dalszej kolejności, aby uporządkować procedury badań, stworzone zostały trzy (A, B i C) kwestionariusze (ang. Moral Judgment Interview - MJI). Każdy z kwestionariuszy zawierał trzy hipotetyczne dylematy moralne, po każdym z dylematów sformułowanych jest 9-12 standaryzowanych pytań kontrolnych, zaprojektowanych tak, aby ustalić motywacje, szczegółowe omówienie i wyjaśnienia osądów moralnych danej osoby (Colby i in., 1983, s. 9).

Pierwszy dylemat w kwestionariuszach A i B dotyczy dwóch kwestii: życie i prawo. Drugi dylemat w obu kwestionariuszach odnosi się do konfliktu pomiędzy moralnością/sumieniem, przekonaniami (czy być pobłażliwym wobec kogoś, kto złamał prawo niezgodnie ze swoim sumieniem) i karą (czy ukarać kogoś, kto złamał prawo). Trzeci dylemat zawiera konflikt między władzą (np. czy być posłusznym rodzicom) i kontraktem (przestrzegać umowy lub wymagać od kogoś przestrzegania umowy; Colby i in., 1983, s. 9-10).

The Adapted Moral Judgment Interview (AMJ)

James Weber i David Wasieleski (2001) zaadaptowali oryginalny MJI do celów swoich badań, które zrealizowali wśród menedżerów. Opracowali trzy opisy problemów moralnych.

Dylemat pierwszy - „Heinz” dotyczy problemu kradzieży przez męża lekarstwa dla chorej na raka żony i jest identyczny $\mathrm{z}$ dylematem pierwszym $\mathrm{z}$ kwestionariusza MJI przedstawionego powyżej.

Dylemat drugi - „Evelyn” odnosi się do fałszownia w przedsiębiorstwie wyników badań przyczyny usterek samochodów.

Dylemat trzeci - „Roger” wiąże się z fałszowaniem raportu firmy audytorskiej zajmującej się badaniem sprawozdania finansowego.

Do każdego z opisanych trzech problemów dołączona była lista siedmiu pytań, które miały służyć zidentyfikowaniu, na którym poziomie rozwoju moralnego znajdują się argumenty podawane przez badaną osobę. Uczestnicy badań odpowiadali na piśmie na zadane pytania, zachęcano ich, aby opisowe wyjaśnienia były wyczerpujące, ponieważ wyjaśnienia krótkie nie mają wartości dla badających. Autorzy kwestionariusza AMJI podają, że odpowiedzi na pytania są mniej ważne od uzasadnień odpowiedzi (Weber, Wasieleski, 2001, s. 104). 
Po zebraniu od respondentów pisemnych odpowiedzi następuje ręczna ocena przy wykorzystaniu systemu punktacji bazującego na rozwiązaniach Kohlberga.

\section{Defining Issues Test (DIT)}

Kolejnym narzędziem do identyfikowania etapu rozwoju moralnego określonej osoby jest opracowany przez Resta i jego współpracowników kwestionariusz DIT (Rest i in., 1999). Beverly Kracher, Abha Chatterjee i Arlene Lundquist (2002) uważają, że DIT jest szeroko wykorzystywanym narzędziem do pomiaru CMD - zastosowano go w ponad 1000 badaniach w ponad 40 krajach.

Kwestionariusz DIT zawiera pięć dylematów moralnych. Zarówno pytania, jak i odpowiedzi są wystandaryzowane, tzn. uczestnicy badań udzielają odpowiedzi, wybierając jedynie ustalone warianty. Nie ma tu otwartych pytań jak w testach MJI i AMJI, co umożliwia szybkie badanie dużej liczby osób (także przez internet) i automatyczne opracowanie wyników. Dylematy z testu DIT (Rest, Navarez, 1998) dotyczą następujących zagadnień:

Dylemat pierwszy - głód w indyjskiej wiosce i kradzież żywności.

Dylemat drugi - ujawnienie przestępczej przeszłości znanego i szanowanego polityka.

Dylemat trzeci - zebranie rady szkoły w sprawie likwidacji placówki.

Dylemat czwarty - kobieta chora na raka i eutanazja.

Dylemat piąty - protesty studentów przeciwko wykorzystywaniu armii Stanów Zjednoczonych do załatwiania interesów gospodarczych.

Badania przy wykorzystaniu testu DIT mogą być prowadzone online lub w wersji tradycyjnej. Trzeba przekazać zebrane dane do centrum badań (Center for the Study of Ethical Development) ${ }^{1}$, które znajduje się na uniwersytecie w Alabamie i w przeciągu dwóch tygodni uzyskuje się wyniki. Nie jest możliwe samodzielne opracowanie wyników tego testu. Podobnie jak w innych testach, nie są tu najważniejsze odpowiedzi na dylematy moralne, ale uzasadnienia tych odpowiedzi, które pozwalają oszacować, na jakim etapie rozwoju moralnego znajduje się badana osoba.

Test DIT był przez wiele lat używany przez badaczy, jednak w ostatnim czasie pojawiło się na jego temat sporo krytycznych opinii. Według Trevino (1992) test DIT jest nieodpowiedni do określenia, na którym etapie wnioskowania moralnego (pierwszy-szósty) znajduje się dana osoba, ponieważ jest tu stosowany wskaźnik $p$, który mierzy, w jakim stopniu badana osoba akceptuje etapy piąty i szósty, nie uwzględniając etapów wcześniejszych.

Podobnie Allen D. Blay i współpracownicy $(2018$, s. 197) uważają, że coraz większa liczba badaczy postrzega DIT jako wadliwy miernik poziomu moralnego rozumowania. Dann G. Fisher i John T. Sweeney (1998, s. 905) wskazują, że „DIT w dużej

1 Pobrane z: https://ethicaldevelopment.ua.edu/ordering-information.html (20.12.2021). 
mierze rejestruje relatywizm badanej osoby i jej liberalne poglądy polityczne". Charles Bailey, Stephen Thoma i Irena Scott (2010, s. 1) piszą, iż „DIT stracił swoją użyteczność lub, co gorsza, okazał się wadliwą miarą oceny etycznej”. Wyniki uzyskane przez Fishera i Sweeneya (1998) wskazują również, że na rezultaty otrzymane za pomocą DIT może wpływać aspekt ideologii politycznej, który nie odzwierciedla dojrzałości oceny moralnej. Badani obniżyli swoje oceny moralne, odpowiadając na dylematy DIT z perspektywy konserwatywnej. W przeciwieństwie do teorii rozwoju moralnego ankietowani byli w stanie zwiększyć swoje oceny moralne, odpowiadając z perspektywy politycznego liberała (Fisher, Sweeney, 1998).

\section{Moral Judgment Test (MJT)}

W 1978 roku Georg Lind z uniwersytetu w Konstanz opublikował pracę prezentującą kolejny test oceny moralnej. W teście MJT zawarte są dwa dylematy moralne.

Dylemat pierwszy - kradzież. Pewna firma bez powodu zwalnia ludzi z pracy. Pracownicy podejrzewają, że dyrekcja założyła podsłuch i wykorzystuje go przeciwko nim. Ale zarząd stanowczo się tego wypiera. Zwolnienia nie ustają, jednak związek zawodowy nie może bronić ludzi, dopóki nie ma niezbitych dowodów. Dlatego dwaj pracownicy włamują się do pomieszczeń dyrekcji i wykradają taśmy z nagraniami. Mają teraz jawny dowód podsłuchu.

Dylemat drugi - eutanazja. Pewna kobieta chorowała na raka i nie było już dla niej ratunku. Cierpiała straszliwe bóle i była tak osłabiona, że większa dawka środka przeciwbólowego, np. morfiny, mogłaby przyspieszyć jej śmierć. Pewnego dnia, czując się trochę lepiej, poprosiła lekarza, aby podał jej więcej leku. Mówiła, że nie może już znieść bólu, a i tak niedługo umrze. Po zastanowieniu lekarz dał jej zwiększoną dawkę morfiny.

W teście MJT są tylko pytania zamknięte i trzeba wybierać gotowe warianty odpowiedzi. Najpierw jest pytanie ogólne, czy respondent popiera podjęte działanie, a następnie wskazana jest seria argumentów za i przeciw podjętej decyzji. Argumenty są formułowane na różnych poziomach wnioskowania moralnego (1-6) i należy zaznaczyć, w jakim stopniu akceptuje się podany argument. Ocenia się argumenty za i przeciw podjętej decyzji. Na tej podstawie można określić, w jakim stopniu badana osoba akceptuje każdy z sześciu poziomów moralnego wnioskowania.

Podsumowując rozważania dotyczące zaprezentowanych dylematów i testów, można wyciągnąć następujące wnioski:

(1) Początkowo testy miały postać pytań otwartych (MJT, AMJI), a później pytań zamkniętych (DIT, MJT), co umożliwiło rozszerzenie skali badań i ich przyspieszenie. 
(2) W każdym z testów jest dylemat dotyczący kradzieży (leku, jedzenia, nagrań), zmieniane są jedynie miejsce kradzieży i kradziony przedmiot.

(3) W teście MJI, a także częściowo w AMJI są dylematy skierowane do dzieci (na początku Kohlberg badał tylko dzieci), później rozszerzano zakres badań i formułowano dylematy odnoszące się do ludzi dorosłych.

(4) W trzech z czterech omówionych testów pojawia się problem eutanazji $\mathrm{w}$ niemal niezmienionej formie.

(5) W przypadku testów MJT i AMJT do oceny wyników trzeba zaangażować przeszkolonych badaczy, w przypadku testów DIT oraz MJT można automatycznie otrzymać wyniki. W teście DIT kalkulacja wyników jest utajniona i płatna, w przypadku testu MJT można samodzielnie przeprowadzić wymagane obliczenia.

3. Wykorzystanie teorii dwuaspektowej (ang. Dual Aspect Theory) do identyfikacji uwarunkowań kognitywnego rozwoju moralnego studentów kierunku zarządzanie

Jak pisze Lind (1999), najbardziej unikalną cechą testu MJT jest możliwość jednoczesnej oceny dwóch aspektów moralnej oceny zachowania - kognitywnego i afektywnego. Wynika to z faktu, że test jest zakorzeniony w teorii dwuaspektowej, według której dla wyczerpującego opisu zachowania moralnego należy uwzględnić dwa aspekty: afektywny i kognitywny. Pełny opis moralnego zachowania osoby obejmuje: (a) moralne idee i pryncypia, które dostarczają informacji, (b) zdolności kognitywne, które posiada osoba, gdy stosuje te idee i pryncypia w swoim procesie podejmowania decyzji (Lind, 1999).

Lind określa test MJT mianem nowoczesnego, kognitywno-strukturalnego podejścia do pomiarów psychologicznych. Według niego „MJT nie jest testem w tradycyjnym rozumieniu. Jest to wielowymiarowy eksperyment behawioralny w formie kwestionariusza" (Lind, 2011, s. 576, por. 2012). MJT umożliwia ocenę zdolności ludzi do oceny argumentów za i przeciw na temat kontrowersyjnego dylematu moralnego na bazie swoich własnych pryncypiów. Oprócz tego pozwala ocenić stosunek, nastawienie, orientację i pogląd odnośnie do sześciu etapów wnioskowania moralnego sformułowanych przez Kohlberga. Daje możliwość oceny, w jakim stopniu osoba akceptuje każdy etap. Tak jak to wcześniej przedstawiono, test zawiera dwa dylematy moralne: kradzież (historię o robotnikach, którzy włamali się do pomieszczeń zarządu przedsiębiorstwa) i eutanazję (historię zaadaptowaną z testu MJI Kohlberga; Lind, Sandberger, Bargel, 1981). Możliwe jest wykorzystanie obu dylematów 
razem do oceny akceptacji stopni rozwoju moralnego lub każdego z dylematów osobno. Testy MJT opracowano w wielu językach, m.in. angielskim i polskim.

Kontekst badań i sformułowanie hipotez badawczych

Głównym pytaniem badawczym tej pracy jest określenie, jakie czynniki (zmienne niezależne) mają związek z poziomem rozwoju moralnego (zmienna zależna). Pewne informacje na ten temat można znaleźć w literaturze przedmiotu.

Moralność a otoczenie kulturowe

Według teorii CMD rozwój wnioskowania moralnego jest uniwersalny z kulturowego punktu widzenia (Trevino, 1992). Leżące u jej podstaw koncepcje i kategorie są uniwersalne we wszystkich kulturach (Trevino, 1992). Jednak, jak uważa Trevino (1986), kultury zorientowane na grupowe podejmowanie decyzji, aktywne zaangażowanie jednostki i wspólną odpowiedzialność mogą się przyczyniać do rozwoju wnioskowania moralnego.

Badania na temat związku otoczenia kulturowego z moralnością prowadził Christie i jego współpracownicy (Christie i in., 2003). Porównując etyczne zachowania menedżerów w Stanach Zjednoczonych, Korei i Indiach, stwierdził, że kultura stanowi istotną determinantę postaw etycznych menedżerów przedsiębiorstw. Z badań tych m.in. wynika, że kultura pełni istotną rolę w etycznym wnioskowaniu i etycznych nastawieniach osoby. Okazało się, że Amerykanie opierają się bardziej na normatywnych teoriach etycznych, natomiast Hindusi i Koreańczycy częściej bazują na czynniku ludzkim, tzn. na relacjach pomiędzy ludźmi zaangażowanymi w określone działania (Christie i in., 2003).

Badania na temat kulturowych uwarunkowań zarządzania konfliktem prowadzili także Christy Corey, Dinah M. Payne i L. Y. Fok (2014), którzy uważają, że po pierwsze, narodowość i kultura są ważnymi czynnikami określającymi, jakie są interakcje między ludźmi, a po drugie, prawdopodobieństwo błędów w komunikacji, nieporozumień i konfliktów jest większe w przedsiębiorstwach międzynarodowych z powodu różnic między kulturami. Tak jak kultura kształtuje społeczeństwa, tak samo wpływa ona na różnice w procesach podejmowania decyzji.

Wiele badań dostarcza wsparcia dla uniwersalności CMD, tzn. niezmienną kolejność etapów rozwoju moralnego każdego człowieka, to jednak niektóre badania pokazują różnice pomiędzy kulturami wschodnimi i zachodnimi (Kracher i in., 2002). Klaus M. Leisinger (2015, s. 13) pisze:

Różnice wynikające z kultury mogą być związane z istotnymi różnicami normatywnymi. Dlatego ich rezultatem mogą być widoczne zmiany w poglądach na to, co powinno być ocenione jako pożądane (odpowiednie), uczciwe, sprawiedliwe 
lub odpowiedzialne. Różnice te powodują także przywiązywanie różnej wagi do sprzecznych norm.

Kracher i Robert P. Marble (2008) badali m.in. różnice rozwoju moralnego, wykorzystując test DIT w Stanach Zjednoczonych i Indiach. Ich wyniki wskazują, że studenci ze Stanów Zjednoczonych mają wyższy współczynnik $P(37,2$ i 35,3$)$ testu DIT, ale różnice te nie były istotne statystycznie $(F=0,54, p>0,05)$.

Badania na temat akceptowania poziomów rozwoju moralnego przez osoby z różnych krajów (Niemcy, Austria, Holandia, Polska, Jugosławia) prowadził Lind (1986). Podsumowując uzyskane wyniki, twierdzi on, że studenci z Europy Wschodniej i Zachodniej ujawniają taką samą kolejność preferencji dla sześciu etapów rozwoju moralnego (ang. stages), jednak, jak dalej pisze Lind, studenci z pięciu badanych krajów różnili się istotnie w konsekwentnym stosowaniu zasad moralnych dla dylematu moralnego eutanazji (rysunek 2).

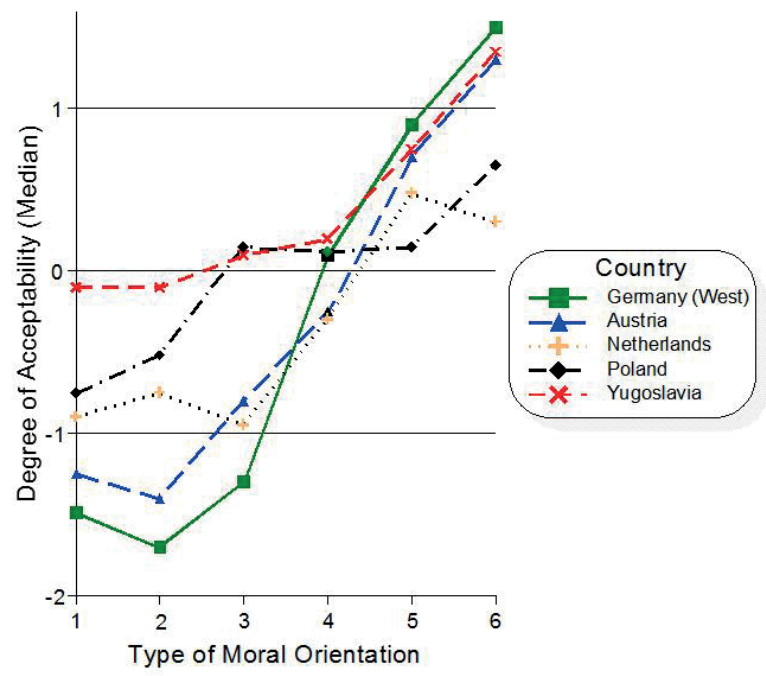

Rysunek 2. Akceptowanie przez studentów z różnych krajów etapów rozwoju moralnego Źródło: Lind, 1986.

Biorąc pod uwagę przedstawione poglądy innych badaczy, można sformułować pierwszą hipotezę badawczą:

H1: Rozwój moralny przyszłych menedżerów (studentów zarządzania) ma związek z krajem pochodzenia i tym samym ze środowiskiem kulturowym. 
Moralność a religijność

W badaniach dotyczących rozwoju moralnego wielokrotnie wskazywano na uwarunkowania związane z religią. Ujmując rzecz ogólnie, Bala Ramasamy, Matthew C. H. Yeung i Alan K. M. Au (2010) piszą, że religijność stanowi tło dla oceny etycznej oraz wpływa na postawę i zachowanie. James M. Day (2017) traktuje to dość jednoznacznie i twierdzi, że przynależność religijna, wiara i jej praktykowanie są często skorelowane z postawami prospołecznymi, takimi jak: empatia, ogólna troska o innych, wolontariat, docenianie życzliwości i postrzegana gotowość do pomagania innym w niebezpieczeństwie, co można postrzegać jako cechy wysokiego rozwoju moralnego w kategoriach Kohlberga.

Wielokrotnie badano rozwój moralny osób religijnych w Stanach Zjednoczonych z wykorzystaniem testu DIT i tu wyniki nie były jednoznaczne. Jak pisze Bruce M. Sabin (2006), często okazywało się, że osoby deklarujące, iż są chrześcijanami, uzyskiwały wynik na poziomie średniej krajowej, jednak wiele innych badań wykazało, że chrześcijanie uzyskiwali wynik poniżej średniej. Jerry L. Tatum i współpracownicy (Tatum i in., 2013) badali za pomocą testu DIT związek między przynależnością religijną uczniów pierwszego roku college'u a ich rozwojem moralnym. Wyniki wskazały, że osoby, które nie deklarowały żadnych preferencji religijnych, miały znacznie wyższe wyniki $P(M=45,2)$ niż respondenci, którzy zidentyfikowali się jako katolicy $(M=36,1)$ lub jako protestanci $(M=38,6)$.

Niektórzy badacze zwracają jednak uwagę na pewne ograniczenia teorii Kohlberga odnośnie do oceny poziomu rozwoju moralnego ludzi religijnych (Scott, Davison, 1992). Przykładowo Jeanette A. Lawrence (1979) badała fundamentalistów religijnych, wykorzystując test DIT, i odkryła, że niektórzy ludzie bardziej preferują czwarty etap rozwoju moralnego niż etapy poziomu postkonwencjonalnego (piąty i szósty), ponieważ etap czwarty daje poczucie harmonii z ich odczuciami religijnymi. Podobnie ujmuje to Richards P. Scott (1991, s. 361), pisząc: „wyniki wielu badań sugerują, że ludzie religijni i konserwatywni mają tendencję do większego preferowania etapu 4 wnioskowania moralnego". Pewnym wytłumaczeniem jest tu sama konstrukcja testu DIT, ponieważ bada on (wykorzystując współczynnik $P$ ) stopień preferowania przez daną osobę fazy postkonwencjonalnej rozwoju moralnego (Robin i in., 1996).

Biorąc pod uwagę te zróżnicowane opinie na temat związku rozwoju moralnego z moralnością, można sformułować hipotezę drugą:

H2: Rozwój moralny przyszłych menedżerów ma związek z ich religijnością.

Weryfikacja hipotez badawczych

W badaniach empirycznych wykorzystano polską i angielską wersję testu MJT i zgromadzono opinie studentów z czterech krajów: Polski (351), Ukrainy (58), 
Bułgarii (54), Stanów Zjednoczonych (63) - razem 526 uczestników. Na początku sprawdzono, w jakim stopniu badane osoby akceptują poszczególne sześć etapów rozwoju moralnego. Rezultaty zaprezentowano w tabeli 1 i na rysunku 3.

Tabela 1. Poziom akceptacji etapów rozwoju moralnego przez cztery grupy wyróżnione z punktu widzenia kraju pochodzenia przy wykorzystaniu dwóch dylematów moralnych testu MJT

\begin{tabular}{cccccccc}
\hline & & \multicolumn{7}{c}{ Etapy rozwoju moralnego } \\
\cline { 3 - 8 } Kraj pochodzenia & $N$ & $\mathbf{1}$ & 2 & 3 & $\mathbf{4}$ & $\mathbf{5}$ & 6 \\
\hline Polska & 88 & $-0,0043$ & $-0,9195$ & $-0,1560$ & 0,7806 & 0,8860 & 0,8262 \\
\hline Ukraina & 260 & $-0,0603$ & $-0,2672$ & 0,2241 & 1,1034 & 0,9267 & 1,0991 \\
\hline Bułgaria & 125 & $-0,1852$ & $-0,0926$ & 0,2639 & 0,5602 & 1,0046 & 0,9167 \\
\hline Stany Zjednoczone & 57 & $-0,4524$ & $-0,6230$ & $-0,1627$ & 0,3254 & 0,7857 & 0,4405 \\
\hline $\begin{array}{c}\text { Poziom ufności } \\
\text { różnicy średnich }\end{array}$ & & 0,024 & $<0,001$ & 0,017 & $<0,001$ & 0,663 & 0,004 \\
\hline
\end{tabular}

Źródło: opracowanie własne.

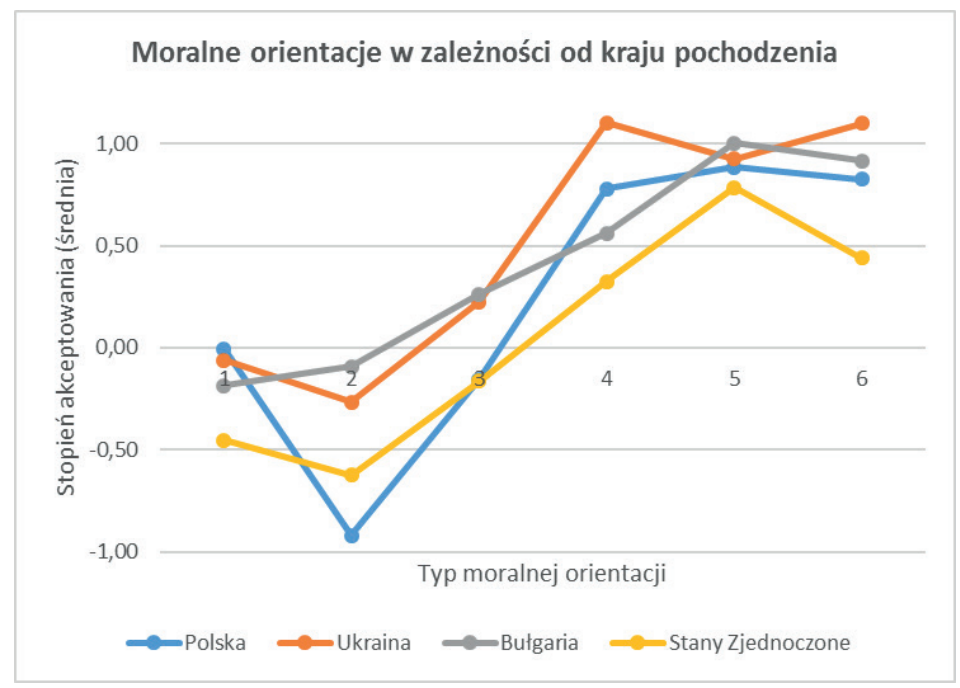

Rysunek 3. Moralne orientacje w zależności od kraju pochodzenia Źródło: opracowanie własne.

Jak można odnotować, statystycznie istotne różnice wystąpiły dla wszystkich etapów moralnego wnioskowania $\mathrm{z}$ wyjątkiem piątego (ostatni wiersz tabeli 1). 
W dalszym etapie podzielono badane osoby na cztery grupy deklarujące wysoką, średnią i niską religijność, a także ateistów (tabela 2 i rysunek 4).

Tabela 2. Poziom akceptacji etapów rozwoju moralnego przez cztery grupy wyróżnione z punktu widzenia poziomu religijności przy wykorzystaniu dwóch dylematów moralnych testu MJT

\begin{tabular}{cccccccc}
\hline & & \multicolumn{7}{c}{ Etapy rozwoju moralnego } \\
\cline { 3 - 8 } Poziom religijności & $N$ & $\mathbf{1}$ & 2 & $\mathbf{3}$ & $\mathbf{4}$ & $\mathbf{5}$ & $\mathbf{6}$ \\
\hline Wysoki & 88 & $-0,0172$ & $-0,9368$ & 0,0603 & 0,7040 & 0,7672 & 0,9454 \\
\hline Średni & 260 & $-0,0917$ & $-0,5975$ & 0,0907 & 0,8002 & 0,9508 & 0,8649 \\
\hline Niski & 125 & $-0,0380$ & $-0,7200$ & $-0,1500$ & 0,7600 & 0,8460 & 0,8160 \\
\hline Ateista & 57 & $-0,1974$ & $-0,8596$ & $-0,6009$ & 0,5877 & 0,8553 & 0,4737 \\
\hline $\begin{array}{c}\text { Poziom ufności } \\
\text { różnicy średnich }\end{array}$ & & 0,7650 & 0,0980 & 0,0000 & 0,5441 & 0,4240 & 0,0430 \\
\hline
\end{tabular}

Źródło: opracowanie własne.

Jak można zauważyć, statystycznie istotne różnice pojawiły się tylko dla etapów trzeciego i szóstego.

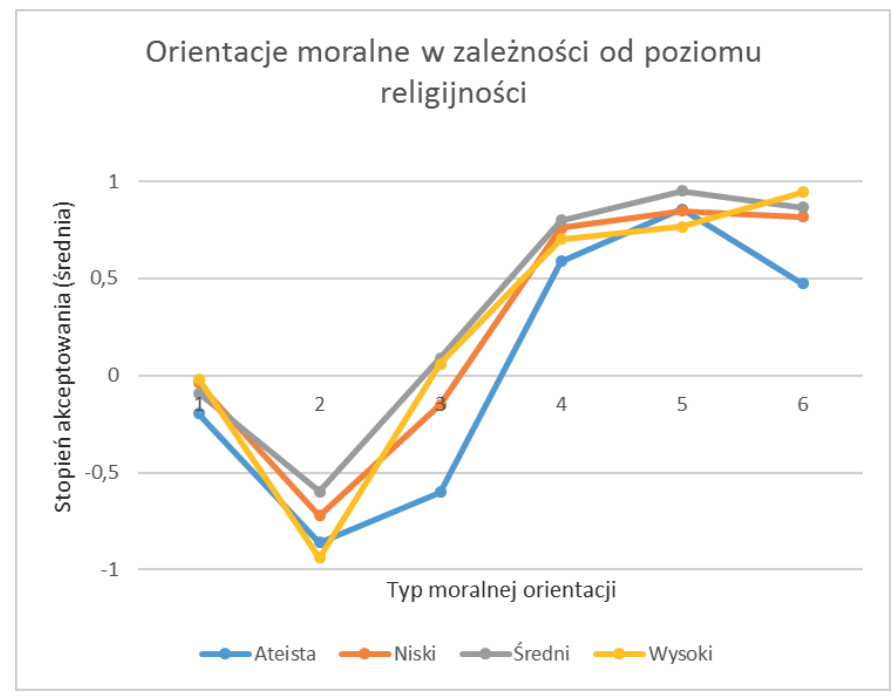

Rysunek 4. Stopień akceptowania każdego z sześciu etapów rozwoju moralnego dla czterech grup religijności

Źródło: opracowanie własne. 
Wskaźnik rozwoju moralnego

Z wcześniejszych rozważań przedstawionych w punkcie 2 wynika, że wnioskowanie moralne określonej osoby nie odbywa się jedynie na jednym etapie rozwoju moralnego, ale obejmuje etap najwyższy osiągnięty przez daną osobę, jak i etapy niższe. Aby to uwzględnić, wykorzystany zostanie zaproponowany przez Dinah Payne, Marka Pawlaka i Sathiadeva Mahesha (2018) współczynnik rozwoju moralnego MDI, który jest określany na podstawie stopnia akceptowalności wszystkich etapów, a także uwzględnia, że etapy wyższe są lepsze niż etapy niższe.

$$
\begin{aligned}
M D I=5\left(r_{6}-\right. & \left.r_{1}\right)+4\left(r_{6}-r_{2}\right)+3\left(r_{6}-r_{3}\right)+2\left(r_{6}-r_{4}\right)+\left(r_{6}-r_{5}\right)+4\left(r_{5}-r_{1}\right) \\
& +3\left(\mathrm{r}_{5}-\mathrm{r}_{2}\right)+2\left(\mathrm{r}_{5}-\mathrm{r}_{3}\right)+\left(\mathrm{r}_{5}-\mathrm{r}_{4}\right)+3\left(r_{4}-r_{1}\right)+2\left(\mathrm{r}_{4}-\mathrm{r}_{2}\right)+\left(\mathrm{r}_{4}-\mathrm{r}_{3}\right) \\
& +2\left(r_{3}-r_{1}\right)+\left(\mathrm{r}_{3}-\mathrm{r}_{2}\right)+\left(r_{2}-r_{1}\right)
\end{aligned}
$$

gdzie:

$r_{\mathrm{i}}$ - stopień akceptowalności etapu $i$.

Przy wykorzystaniu tego wskaźnika można określić rozwój moralny, biorąc pod uwagę stopień akceptowania przez osobę lub grupę osób każdego z sześciu etapów rozwoju. Można także obliczyć wskaźnik, analizując oba proponowane przez Linda dylematy moralne lub każdy z dylematów oddzielnie.

\section{Weryfikacja hipotezy $\mathrm{H} 1$}

$\mathrm{W}$ celu zweryfikowania hipotezy $\mathrm{H} 1$ przeprowadzono test istotności różnic średnich $M D I$ dla osób z rozpatrywanych czterech krajów; nie stwierdzono istotnych statystycznie różnic. Wyniki przedstawiono w tabeli 3. Można zatem stwier-

\begin{tabular}{|c|c|c|c|c|c|c|}
\hline \multicolumn{7}{|c|}{ Jednoczynnikowa ANOVA } \\
\hline & & Suma & & Średni & & \\
\hline & & kwadratów & $d f$ & kwadrat & $F$ & Istotność \\
\hline \multirow{3}{*}{$\begin{array}{c}\text { Oba dylematy } \\
\text { moralne }\end{array}$} & między grupami & 364,410 & 3 & 121,470 &, 182 & ,908 \\
\hline & wewnątrz grup & 347832,210 & 522 & 666,345 & & \\
\hline & ogółem & 348196,620 & 525 & & & \\
\hline \multirow{3}{*}{$\begin{array}{c}\text { Dylemat } \\
\text { pracowników }\end{array}$} & między grupami & 3552,563 & 3 & 1184,188 & ,967 & ,408 \\
\hline & wewnątrz grup & 641736,080 & 524 & 1224,687 & & \\
\hline & ogółem & 645288,643 & 527 & & & \\
\hline
\end{tabular}
dzić, że nie ma różnic rozwoju moralnego osób z badanych krajów.

Tabela 3. Test istotności różnic średnich MDI dla osób z czterech krajów 


\begin{tabular}{|c|c|c|c|c|c|c|}
\hline \multicolumn{7}{|c|}{ Jednoczynnikowa ANOVA } \\
\hline & & Suma & & Średni & & \\
\hline & & kwadratów & $d f$ & kwadrat & $F$ & Istotność \\
\hline \multirow[t]{3}{*}{ Dylemat doktora } & między grupami & 2835,240 & 3 & 945,080 & ,909 & ,436 \\
\hline & wewnątrz grup & 542766,375 & 522 & 1039,782 & & \\
\hline & ogółem & 545601,615 & 525 & & & \\
\hline
\end{tabular}

Źródło: opracowanie własne.

\section{Weryfikacja hipotezy $\mathrm{H} 2$}

W celu zweryfikowania hipotezy $\mathrm{H} 2$ przeprowadzono test porównania różnic istotności średnich średniego MDI dla osób deklarujących różne poziomy religijności; nie stwierdzono istotnych statystycznie różnic. Wyniki pokazano w tabeli 4. Można zatem stwierdzić, że nie ma różnic rozwoju moralnego osób deklarujących różny poziom religijności.

Tabela 4. Test istotności różnic średnich MDI dla osób deklarujących różny poziom religijności

\begin{tabular}{|c|c|c|c|c|c|c|}
\hline \multicolumn{7}{|c|}{ Jednoczynnikowa ANOVA } \\
\hline & & $\begin{array}{c}\text { Suma } \\
\text { kwadratów }\end{array}$ & $d f$ & $\begin{array}{l}\text { Średni } \\
\text { kwadrat }\end{array}$ & $F$ & Istotność \\
\hline \multirow{3}{*}{$\begin{array}{l}\text { Oba dylematy } \\
\text { moralne }\end{array}$} & między grupami & 271,203 & 3 & 90,401 & ,137 & ,938 \\
\hline & wewnątrz grup & 344898,024 & 524 & 658,202 & & \\
\hline & ogółem & 345169,227 & 527 & & & \\
\hline \multirow{3}{*}{$\begin{array}{c}\text { Dylemat } \\
\text { pracowników }\end{array}$} & między grupami & 681,503 & 3 & 227,168 & 191 & ,902 \\
\hline & wewnątrz grup & 625342,450 & 526 & 1188,864 & & \\
\hline & ogółem & 626023,953 & 529 & & & \\
\hline \multirow[t]{3}{*}{ Dylemat doktora } & między grupami & 2777,865 & 3 & 925,955 &, 870 & ,456 \\
\hline & wewnątrz grup & 557735,113 & 524 & 1064,380 & & \\
\hline & ogółem & 560512,977 & 527 & & & \\
\hline
\end{tabular}

Źródło: opracowanie własne.

Dodatkowe obliczenia wykazały także, że nie ma istotnych statystycznie różnic w rozwoju moralnym osób, które deklarują, iż są religijne $(M D I=28,43)$ i osób, które deklarują, że są ateistami $(M D I=27,07)$. Szczegółowe wyniki porównań rozwoju moralnego osób deklarujących różny poziom religijności przedstawia rysunek 5. 


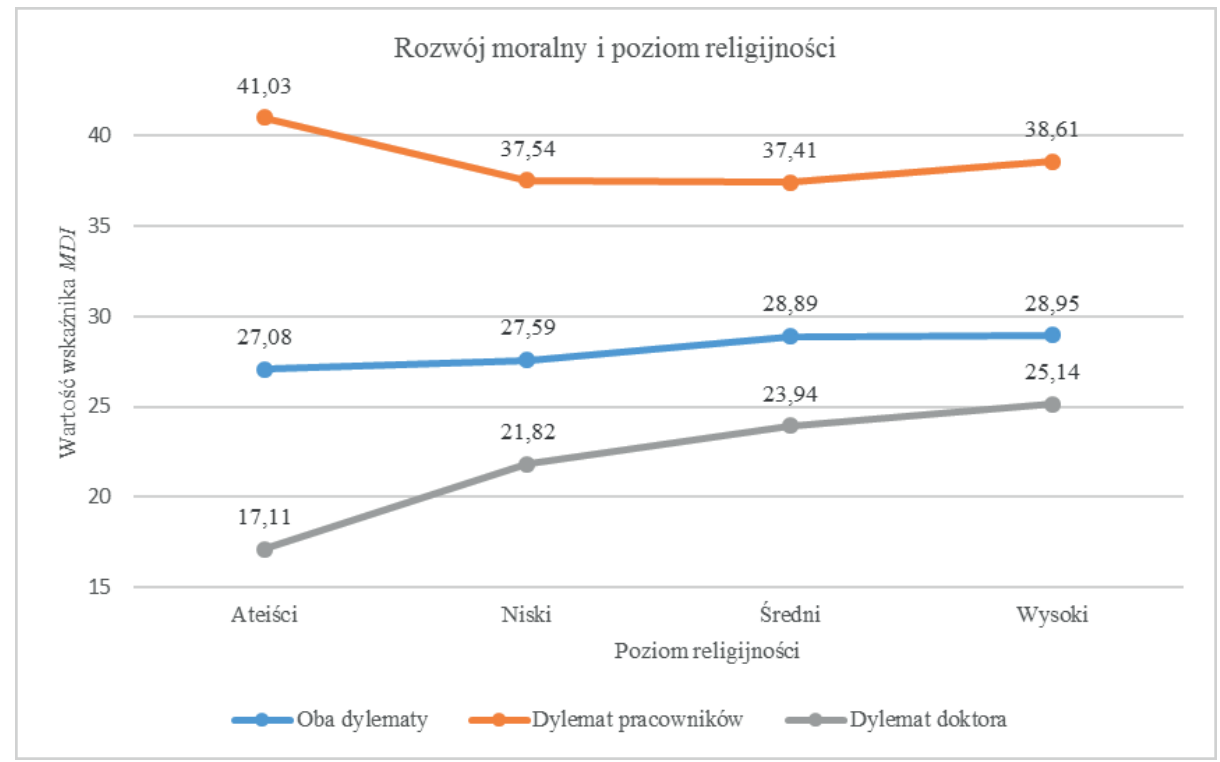

Rysunek 5. Poziomy religijności i wskaźnik rozwoju moralnego - wyniki uzyskane z wykorzystaniem MJT

Źródło: opracowanie własne.

Jak wynika z rysunku 5, jeśli weźmiemy pod uwagę całą badaną grupę i oba dylematy moralne, to w miarę jak poziom religijności wzrasta, wzrasta także poziom rozwoju moralnego. Różnice nie są jednak istotne statystycznie. Jeszcze wyraźniej tendencja ta jest widoczna w przypadku dylematu doktora, natomiast w przypadku dylematu pracowników taka tendencja nie występuje.

Porównanie wyników uzyskanych przy wykorzystaniu różnych dylematów moralnych

W opisywanych badaniach wykorzystane zostały dwa dylematy moralne zaproponowane przez Linda w kwestionariuszu MJT. Jeśli porównamy ocenę rozwoju oralnego dla całej badanej grupy osób, wykorzystując te dwa dylematy, otrzymamy statystycznie istotne różnice (tabela 3 s. 90). Świadczy to o tym, że wyniki badań rozwoju moralnego zależą od tego, jaki dylemat moralny zostanie wykorzystany. 
Tabela 5. Oszacowanie rozwoju moralnego całej grupy przy wykorzystaniu dwóch dylematów moralnych

\begin{tabular}{|c|c|c|c|c|c|c|c|}
\hline \multirow{2}{*}{$\begin{array}{c}\begin{array}{c}\text { Dylemat } \\
\text { moralny }\end{array} \\
\text { Dylemat } \\
\text { pracowników }\end{array}$} & \multirow{2}{*}{$\frac{N}{553}$} & \multicolumn{3}{|c|}{ MDI średnia } & $\begin{array}{l}\text { Odchylenie } \\
\text { tandardowe }\end{array}$ & \multicolumn{2}{|c|}{ Błąd standardowy średniej } \\
\hline & & & 38,4439 & & 32,97598 & 1,48733 & \\
\hline \multirow{3}{*}{$\begin{array}{l}\text { Dylemat } \\
\text { doktora }\end{array}$} & 551 & & 22,6525 & & 32,47204 & 1,38336 & \\
\hline & \multicolumn{2}{|c|}{$\begin{array}{l}\text { Test Levene’a jedno- } \\
\text { rodności wariancji }\end{array}$} & \multicolumn{5}{|c|}{ Test równości średnich } \\
\hline & $F$ & Istotność & $t$ & $d f$ & $\begin{array}{c}\text { Istotność } \\
\text { (dwustronna) }\end{array}$ & $\begin{array}{l}\text { Różnica } \\
\text { średnich }\end{array}$ & $\begin{array}{c}\text { Błąd stan- } \\
\text { dardowy } \\
\text { różnicy }\end{array}$ \\
\hline $\begin{array}{l}\text { Założono rów- } \\
\text { ność wariancji }\end{array}$ & 1,997 &, 158 & 7,773 & 1102 &, 000 & 15,79149 & 2,03149 \\
\hline $\begin{array}{l}\text { Nie zało- } \\
\text { żono równości } \\
\text { wariancji }\end{array}$ & & & 7,774 & 1096,545 &, 000 & 15,79149 & 2,03121 \\
\hline
\end{tabular}

Źródło: opracowanie własne.

Tabela 6. Index rozwoju moralnego obliczony na podstawie dwóch dylematów moralnych dla różnych grup religijności

\begin{tabular}{cccccc} 
& & \multicolumn{2}{c}{$\begin{array}{c}\text { Wskaźnik rozwoju moralnego } \\
\text { (średnia) }\end{array}$} & & \\
\cline { 3 - 5 } $\begin{array}{c}\text { Poziom } \\
\text { religijności }\end{array}$ & $N$ & $\begin{array}{c}\text { Dylemat } \\
\text { pracowników }\end{array}$ & Dylemat doktora & $t$ & $\begin{array}{c}\text { Istotność } \\
\text { (dwustronna) }\end{array}$ \\
\hline Wysoki & $88 / 87$ & 38,6080 & 25,1379 & 2,707 &, 007 \\
\hline Średni & $260 / 259$ & 37,4135 & 23,9421 & 4,660 &, 000 \\
\hline Niski & $125 / 125$ & 37,4880 & 21,8160 & 3,627 &, 000 \\
\hline Ateiści & $57 / 57$ & 41,0263 & 17,1053 & 3,539 &, 001 \\
\hline
\end{tabular}

Źródło: opracowanie własne.

Wyniki wskazują, że statystycznie istotne różnice występują dla każdego poziomu religijności. Oznacza to, iż oszacowanie rozwoju moralnego zależy od wykorzystanego dylematu moralnego. W celu dalszego, głębszego zbadania tego zagadnienia wykorzystana została analiza efektów międzyobiektowych. Statystycznie istotne różnice wystąpiły tylko dla dylematu doktora (tabela 7 i rysunek 6). 
Tabela 7. Ocena efektów międzyobiektowych czynników kraj pochodzenia i poziom religijności

\begin{tabular}{|c|c|c|c|c|c|}
\hline \multicolumn{6}{|c|}{ Testy efektów międzyobiektowych } \\
\hline \multicolumn{6}{|c|}{ Zmienna zależna: $M D I$ - dylemat doktora } \\
\hline Źródło & $\begin{array}{l}\text { Typ III sumy } \\
\text { kwadratów }\end{array}$ & $d f$ & Średni kwadrat & $F$ & Istotność \\
\hline Model skorygowany & $27616,795^{\mathrm{a}}$ & 15 & 1841,120 & 1,810 &, 031 \\
\hline Stała & 55825,805 & 1 & 55825,805 & 54,897 &, 000 \\
\hline Kraj pochodzenia & 1595,162 & 3 & 531,721 &, 523 & ,667 \\
\hline Poziom religijności & 1741,688 & 3 & 580,563 &, 571 & ,634 \\
\hline $\begin{array}{l}\text { Kraj pochodzenia* } \\
\text { Poziom religijności }\end{array}$ & 21437,993 & 9 & 2381,999 & 2,342 &, 014 \\
\hline Błąd & 500324,197 & 492 & 1016,919 & & \\
\hline Ogółem & 796581,000 & 508 & & & \\
\hline Ogółem skorygowane & 527940,992 & 507 & & & \\
\hline & ${ }^{a}$ R kwadrat & koryg & $\mathrm{R}$ kwadrat $=, 023$ ) & & \\
\hline
\end{tabular}

Źródło: opracowanie własne.

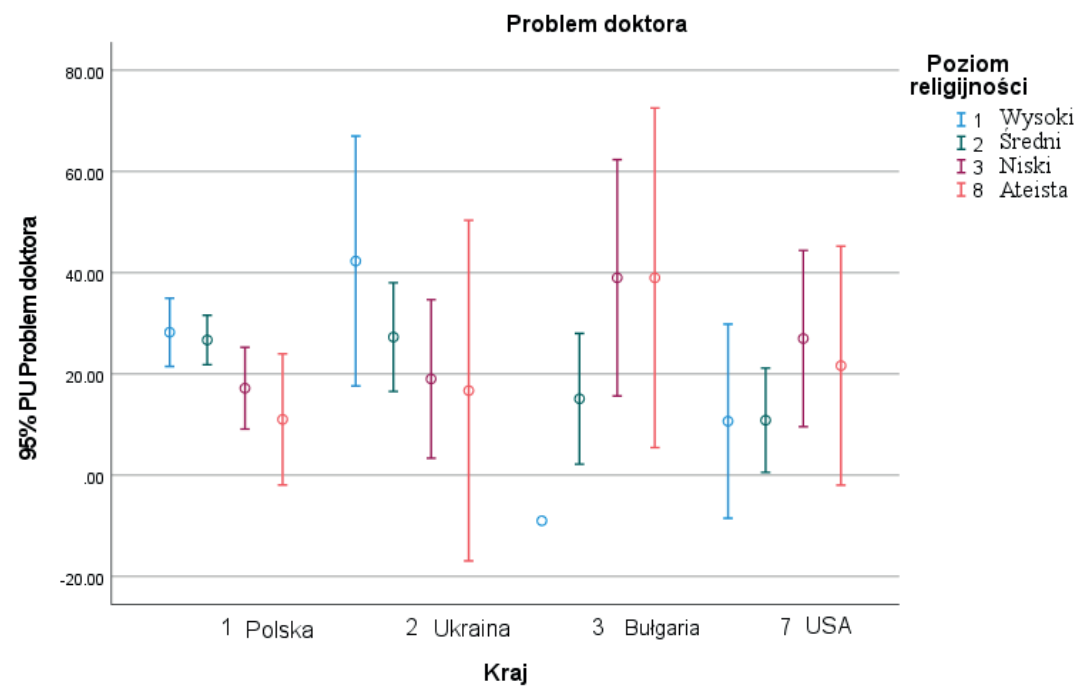

Rysunek 6. Pogrupowany wykres błędów średniej dla dylematu doktora dla krajów i poziomów religijności

Źródło: opracowanie własne. 
Przy wykorzystaniu rezultatów dla całej badanej populacji i dylematu doktora można powiedzieć, że wpływ poziomu religijności na MDI jest nieistotny. Ponadto stwierdza się, że wpływ kraju pochodzenia na MDI jest także nieistotny. Jednak jest istotna statystycznie $(0,014)$ interakcja pomiędzy poziomem religijności a krajem pochodzenia i jej wpływ na $M D I$.

Podobne wnioski można wyciągnąć, analizując rysunek 6. Jeśli weźmiemy pod uwagę Polskę i Ukrainę, to możemy zauważyć, że w miarę jak spada poziom religijności, spada także wartość indeksu rozwoju moralnego. Dla Bułgarii i Stanów Zjednoczonych tendencja jest raczej odwrotna.

Powyższe analizy bardziej szczegółowo przedstawiono w tabelach 8 i 9 oraz na rysunku 7. Różnice pomiędzy poszczególnymi grupami są istotne statystycznie.

Tabela 8. Poziom religijności i index rozwoju moralnego dla studentów z Polski i Ukrainy, rezultaty uzyskane przy wykorzystaniu dylematu doktora

\begin{tabular}{|c|c|c|c|c|c|c|}
\hline & Poziom religijności & & $N$ & $\begin{array}{c}M D I \\
\text { średnia }\end{array}$ & Odchylenie stand & lardowe \\
\hline \multirow{5}{*}{$\begin{array}{l}\text { Dylemat } \\
\text { doktora } \\
\text { Polska } \\
\text { i Ukraina }\end{array}$} & \multicolumn{2}{|l|}{ wysoki } & 75 & 28,7200 & \multicolumn{2}{|l|}{27,82708} \\
\hline & \multicolumn{2}{|l|}{ średni } & 196 & 26,7857 & \multicolumn{2}{|l|}{31,49139} \\
\hline & \multicolumn{2}{|l|}{ niski } & 92 & 17,0054 & \multicolumn{2}{|l|}{34,04607} \\
\hline & \multicolumn{2}{|l|}{ ateista } & 38 & 12,0789 & \multicolumn{2}{|l|}{35,06202} \\
\hline & ogółem & & 401 & 23,5100 & \multicolumn{2}{|l|}{32,19660} \\
\hline \multicolumn{7}{|c|}{ ANOVA } \\
\hline & $\begin{array}{c}\text { Suma } \\
\text { kwadratów }\end{array}$ & $\mathrm{df}$ & & Średni kwadrat & $F$ & Istotność \\
\hline między grupami & 12996,830 & 3 & & 4332,277 & 4,282 &, 005 \\
\hline wewnątrz grup & 401651,630 & 397 & & 1011,717 & & \\
\hline ogółem & 414648,460 & 400 & & & & \\
\hline
\end{tabular}

Źródło: opracowanie własne.

Tabela 9. Poziom religijności i index rozwoju moralnego dla studentów z Bułgarii i Stanów Zjednoczonych, rezultaty uzyskane przy wykorzystaniu dylematu doktora

\begin{tabular}{cccc}
\hline Poziom religijności & $N$ & $\begin{array}{c}\text { MDI } \\
\text { średnia }\end{array}$ & Odchylenie standardowe \\
\hline Wysoki & 10 & 8,7000 & 24,33927 \\
\hline Średni & 55 & 13,1727 & 30,40654 \\
\hline Niski & 30 & 32,6000 & 36,36439 \\
\hline Ateista & 14 & 30,3214 & 31,44874 \\
\hline
\end{tabular}




\begin{tabular}{|c|c|c|c|c|c|c|c|c|}
\hline \multicolumn{3}{|c|}{ Poziom religijności } & $N$ & & $\begin{array}{c}M D I \\
\text { średnia }\end{array}$ & \multicolumn{3}{|c|}{ Odchylenie standardowe } \\
\hline \multicolumn{3}{|c|}{ Ogółem } & 109 & & 20,3119 & \multicolumn{3}{|c|}{32,85038} \\
\hline \multirow[t]{2}{*}{ Model } & efekt & stałe & & & & \multicolumn{3}{|c|}{31,84243} \\
\hline & & & & & & & & \\
\hline \multicolumn{9}{|c|}{ efekty losowe } \\
\hline \multicolumn{4}{|c|}{ Suma kwadratów } & $d f$ & & Średni kwadrat & $F$ & Istotność \\
\hline \multicolumn{2}{|c|}{ Między grupami } & 10084,182 & & 3 & & 3361,394 & 3,315 &, 023 \\
\hline \multicolumn{2}{|c|}{ Wewnątrz grup } & 106463,713 & & 105 & & 1013,940 & & \\
\hline \multicolumn{2}{|c|}{ Ogółem } & 116547,894 & & 108 & & & & \\
\hline
\end{tabular}

Źródło: opracowanie własne.

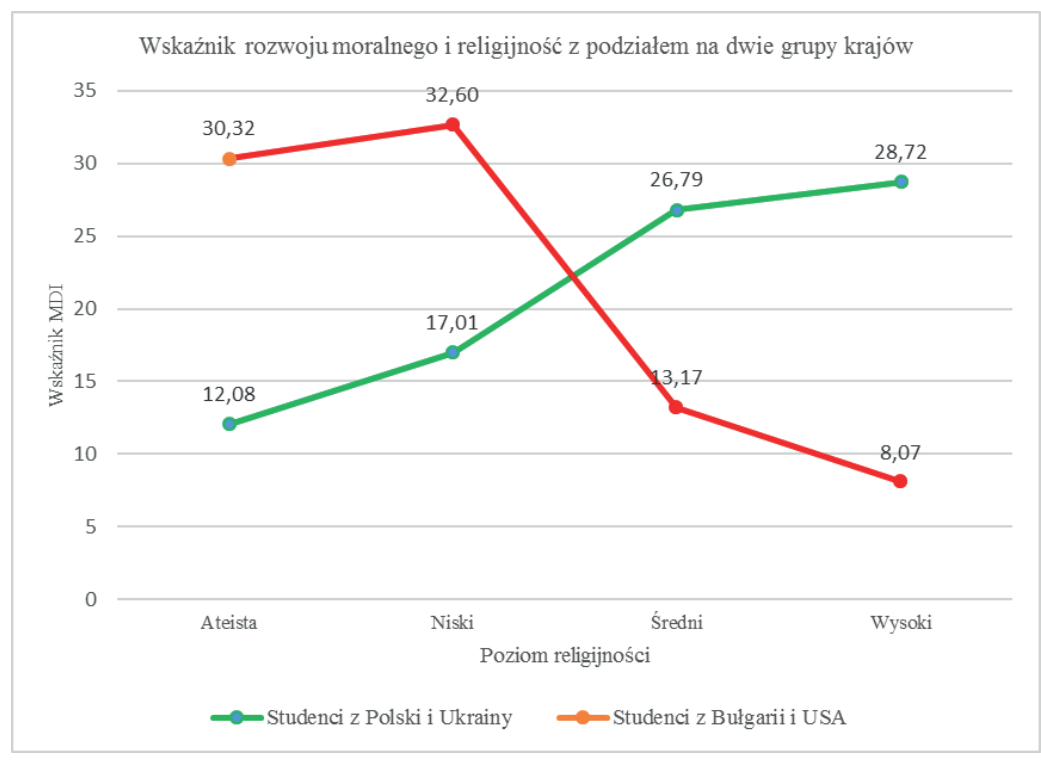

Rysunek 7. Poziom religijności i rozwój moralny studentów z Polski i Ukrainy, a także Bułgarii i Stanów Zjednoczonych oszacowany przy wykorzystaniu dylematu doktora

Źródło: opracowanie własne.

Podsumowując tę część badań, można sformułować następujące wnioski:

(1) Dla całej populacji osób z czterech krajów nie stwierdzono istotnych statystycznie różnic w poziomie rozwoju moralnego. Nie stwierdzono także różnic rozwoju moralnego osób deklarujących, że są religijne i osób, które deklarują, iż są ateistami. 
(2) W przypadku studentów z Polski i Ukrainy w miarę jak rośnie poziom religijności, rośnie także poziom rozwoju moralnego. W przypadku studentów z Bułgarii i Stanów Zjednoczonych tendencja jest odwrotna. Różnice są tu istotne statystycznie.

(3) Oszacowanie poziomu rozwoju moralnego zależy od tego, jaki dylemat moralny jest wykorzystywany. Reakcje na dylemat doktora są inne niż reakcje na dylemat pracowników. Jedynie w przypadku dylematu doktora różnice są istotne statystycznie.

(4) Można także stwierdzić, że w przypadku dylematu moralnego doktora oszacowanie poziomu rozwoju moralnego zależy od interakcji pomiędzy dwoma czynnikami: kraju pochodzenia i poziomu religijności. Dla dylematu pracowników takich interakcji nie stwierdzono.

\section{Podsumowanie}

W badaniach rozwoju moralnego wykorzystujących teorię CMD Kohlberga stosowane są różne dylematy moralne. Przedstawione tu wnioski świadczą o tym, że wyniki takich badań zależą od rodzaju użytego dylematu moralnego. Wskazuje to na konieczność starannego doboru dylematów moralnych do tego rodzaju badań lub zrezygnowania ze stosowania dylematów na rzecz badania systemów wartości (Payne i in., 2018).

Zupełnie różne wyniki badań uzyskano dla osób z Polski i Ukrainy. Tutaj widać wyraźnie, że rozwój moralny zależy od poziomu religijności. Byli to studenci w dużej części z uniwersytetów katolickich, co także nie jest bez znaczenia. Shanda Traiser i Myron Eighmy (2011, s. 326) ujmują to w sposób następujący:

W przypadku studiów na uniwersytetach, które mają przynależność religijną, biznes i etyka są często bardziej wyeksponowane w programie nauczania. Prowadzi to niektóre firmy do skoncentrowania swoich wysiłków rekrutacyjnych na studentach kończących prywatne uczelnie i uniwersytety, które najczęściej mają przynależność religijną, przy założeniu, że kandydaci ci mają wyższy poziom rozwoju moralnego i etycznego niż studenci z instytucji publicznych.

Przedstawione wyniki badań (rysunki 5, 6 i 7) wskazują, że w przypadku studentów z Polski i Ukrainy wysoki poziom religijności jest powiązany z wysoką moralnością. Jest to zgodne z opiniami Day’a (2017, s. 301), który pisze, że „zaangażowanie religijne i praktyki religijne sprzyjają mądrości, powiązanej z lepszym rozwiązywaniem problemów, przyjmowaniem szerszej perspektywy, nadzieją, pokorą, hojnością, tolerancją i lepszą komunikacją z innymi”. Podobnie kwestię 
tę ujmują Patricia Herzog, Daniel Harris i Jared Peifer (2018, s. 3), wskazując, że postawy prospołeczne są powiązane z religijnością.

Przedstawione wyniki badań pokazują ponadto, że dwa czynniki wspólnie oddziałują na poziom rozwoju moralnego przyszłych liderów biznesu - studentów kierunku zarządzanie: kraj pochodzenia i poziom religijności. Wynika z tego praktyczna wskazówka dla osób podejmujących działania rekrutacyjne i poszukujących przyszłych pracowników. Warto wziąć pod uwagę, z jakiego kraju dana osoba pochodzi i czy jest to osoba praktykująca swoją wiarę religijną, czy studiowała na uniwersytecie katolickim. Jest to szczególnie ważne, gdy zależy nam na zatrudnianiu pracowników o wysokiej moralności.

\section{Bibliografia}

Arnold, M. L. (2000). Stage, Sequence, and Sequels: Changing Conceptions of Morality, Post-Kohlberg. Educational Psychology Review, 12(4), 365-383.

Bailey, Ch. D., Scott, I., Thoma, S. (2010). Revitalizing Accounting Ethics Research in the Neo-Kohlbergian Framework: Putting the DIT into Perspective. Behavioral Research in Accounting, 22(2), 1-26.

Blay, A. D., Gooden, E. S., Mellon, M. J., Stevens, D. E. (2018). The Usefulness of Social Norm Theory in Empirical Business Ethics Research: A Review and Suggestions for Future Research. Journal of Business Ethics, 152, 191-206.

Carroll, A. B., Buchholtz, A. K. (2008). Business \& Society: Ethics and Stakeholder Management. New York: South-Western Cengage Learning.

Colby, A., Kohlberg, L., Gibbs, J., Lieberman, M., Fischer, K., Saltzstein, H. D. (1983). A Longitudinal Study of Moral Judgment. Monographs of the Society for Research in Child Development, 48(1-2), 1-124.

Conroy, S. J., Emerson, T. L. N. (2004). Business Ethics and Religion: Religiosity as a Predictor of Ethical Awareness Among Students. Journal of Business Ethics, 50, 383-396.

Christie, P. M. J., Kwon, I. W. G., Stoeberl, P. A., Baumhart, R. (2003). A Cross-Cultural Comparison of Ethical Attitudes of Business Managers: India, Korea and the United States. Journal of Business Ethics, 46(3), 263-287.

Corey, Ch. M., Payne, D. M., Fok, L. Y. (2014). Cross-Cultural Differences in Values and Conflict Management: A Comparison of U.S. and Puerto Rico. Journal of Organizational Culture, Communications and Conflict, 18(2), 59-78.

Day, J. M. (2017). Religion and Human Development in Adulthood: Well-Being, Prosocial Behavior, and Religious and Spiritual Development. Behavioral Development Bulletin, 22(2), 298-313. 
Everett, L., Thorne, D., Danehower, C. (1996). Cognitive Moral Development and Attitudes Toward Women Executives. Journal of Business Ethics, 15(11), 1227-1235.

Fisher, D. G., Sweeney, J. T. (1998). The Relationship between Political Attitudes and Moral Judgment: Examining the Validity of the Defining Issues Test. Journal of Business Ethics, 17, 905-916.

Foo, N. H., Vitell, S. J., Barnes, J. H., Desborde, R. (1997). Ethical Correlates of Role Conflict and Ambiguity in Marketing: The Mediating Role of Cognitive Moral Development. Journal of the Academy of Marketing Science, 25(2), 117-126.

Fraedrich, J., Thorne, D. M., Ferrell, O. C. (1994). Assessing the Application of Cognitive Moral Development Theory to Business Ethics. Journal of Business Ethics, 13(10), 829-838.

Goolsby, J. R., Hunt, S. D. (1992). Cognitive Moral Development and Marketing. Journal of Marketing, 56(1), 55-68.

Graduate Management Admission Council (2005). Application Trends Survey, Executive Summary of Key Findings. Pobrane z: https://www.gmac.com/ market-intelligence-and-research/research-library/admissions-and-application-trends/2005-application-trends-survey-executive-summary-report (12.02.2021).

Graduate Management Admission Council (2016). Application Trends Survey Report. Pobrane $\mathrm{z}$ : https://www.google.com/url?sa=t\&rct=j\&q=\&esrc=s\&source=web\& $\mathrm{cd}=\& v e d=2$ ahUKEwjOhI-z8IfyAhXWCRAIHSLwDkoQFjAAegQICBAD\&url =https $\% 3 \mathrm{~A} \% 2 \mathrm{~F} \% 2 \mathrm{Fwww}$.gmac.com $\% 2 \mathrm{~F}-\% 2 \mathrm{Fmedia} \% 2 \mathrm{Ffiles} \% 2 \mathrm{Fgmac} \% 2$ Fresea rch\%2Fadmissions-and-application-trends\%2F2016-gmac-application-trends-web-release-v2.pdf\&usg=AOvVaw2gAh7JqlnoKs2gSEUScNtq (29.07.2021).

Green, S., Weber, J. (1997). Influencing Ethical Development: Exposing Students to the AICPA Code of Conduct. Journal of Business Ethics, 16, 777-790.

Herzog, P. S., Harris, D. E., Peifer, J. (2018). Facilitating Moral Maturity: Integrating Developmental and Cultural Approaches. Journal of Management, Spirituality \& Religion, 15(5), 450-474.

Izzo, G. (2000). Compulsory Ethics Education and the Cognitive Moral Development of Salespeople: A Quasi-Experimental Assessment. Journal of Business Ethics, 28(3), 223-241.

Kohlberg, L. (1973). The Claim to Moral Adequacy of a Highest Stage of Moral Judgment. The Journal of Philosophy, 70(18), 630-646.

Kohlberg, L. (1963). The Development of Children's Orientations Toward a Moral Order I. Sequence in the Development of Moral Thought. Vita Humana, 6, 11-33.

Kohlberg, L., Candee, D. (1984). The Relationship of Moral Judgment to Moral Action. W: L. Kohlberg (red.), Essays in Moral Development. T. 2. The Psychology of Moral Development (s. 498-581). New York: Harper \& Row. 
Kohlberg, L., Hersh, R. H. (1977). A Theory of Moral Development: A Review of the Theory. Theory into Practice, 16(5), 53-50.

Kracher, B., Chatterjee, A., Lundquist, A. R. (2002). Factors Related to the Cognitive Moral Development of Business Students and Business Professionals in India and the United States: Nationality, Education, Sex and Gender. Journal of Business Ethics, 35(4), 255-268.

Kracher, B., Marble, R. P. (2008). The Significance of Gender in Predicting the Cognitive Moral Development of Business Practitioners Using the Sociomoral Reflection Objective Measure. Journal of Business Ethics, 78, 503-526.

Krebs, D. L., Denton, K. (2005). Toward a More Pragmatic Approach to Morality: A Critical Evaluation of Kohlberg's Model. Psychological Review, 112(3), 629-649.

Lawrence, J. A. (1979). The Component Procedures of Moral Judgment Making (Dissertation Abstracts International 40:896B, University of Minnesota, Minneapolis).

Leisinger, K. M. (2015). Corporate Responsibility in a World of Cultural Diversity and Pluralism of Values. Journal of International Business Ethics, 8(2), 9-31.

Lind, G. (1978). Wie misst Mann moralisches Urteil? Probleme und Möglichkeiten der Messung eines komplexen Konstrukts. W: G. Portele (red.), Sozialisation und Moral: neuere Ansätze zur Moral. Entwicklung und Erziehung. Weinheim: Beltz.

Lind, G. (1986). Cultural Differences in Moral Judgment Competence? A Study of West and East European University Students. Behavior Science Research, 20, 1-4.

Lind, G. (1999). Scoring of the Moral Judgment Test (MJT). University of Konstanz. Pobrane z: http://moralcompetence.net/mut/mjt-engl.htm (6.12.2021).

Lind, G. (2011). Moral Competence and the Democratic Way of Living. Europe's Journal of Psychology, 7(4), 569-596. Pobrane z: https://ejop.psychopen.eu/index.php/ ejop/article/view/153 (6.12.2021).

Lind, G. (2012). Moral Competence and Democratic Ways of Life. W: W. G. Weber, M. Thoma, A. Ostendorf, L. Chisholm (red.), Democratic Competences and Social Practices in Organizations (s. 62-85). Wiesbaden: Springer VS.

Lind, G., Sandberger, J. U., Bargel, T. (1981). Moral Judgment, Ego Strength, and Democratic Orientations: Some Theoretical Contiguities and Empirical Findings. Political Psychology, 3(3-4), 70-110. Pobrane z: https://www.jstor.org/ stable/pdf/3791142.pdf (6.12.2021).

Payne, D., Pawlak, M., Mahesh, S. (2018). The Moral Development Index of Future Business Leaders: A Study on the Impact of Changes in Economic Systems and Gender. Journal of Business and Management, 24(1), 49-78. 
Ramasamy, B., Yeung, M. C. H., Au, A. K. M. (2010). Consumer Support for Corporate Social Responsibility (CSR): The Role of Religion and Values. Journal of Business Ethics, 91, 61-72.

Rest, J. (1986). Moral Development: Advances in Research and Theory. New York: Praeger.

Rest, J., Narvaez, D. (1998). DIT2, Defining Issues Test, University of Minnesota, Center for the Study of Ethical Development. Pobrane z: https:/ethicaldevelopment.ua.edu/about-the-dit.html (6.12.2021).

Rest, J. R., Narvaez, D., Thoma, S. J., Bebeau, M. J. (1999). DIT2: Devising and Testing a Revised Instrument of Moral Judgment. Journal of Educational Psycho$\log y, 91(4), 644-659$.

Roberts, J. A., Wasieleski, D. M. (2012). Moral Reasoning in Computer-Based Task Environments: Exploring the Interplay between Cognitive and Technological Factors on Individuals' Propensity to Break Rules. Journal of Business Ethics, 110, 355-376. DOI: 10.1007/s10551-011-1196-Z.

Robin, D. P., Gordon, G., Jordan, C., Reidenbach, E. R. (1996). The Empirical Performance of Cognitive Moral Development in Predicting Behavioral Intent. Business Ethics Quarterly, 6(4), 493-515.

Sabin, B. M. (2006). A Faith-Based Program Evaluation: Moral Development of Seminary Students at the Louisiana State Penitentiary. Orlando: University of Central Florida.

Scott, R. P. (1991). The Relation between Conservative Religious Ideology and Principled Moral Reasoning: A Review. Review of Religious Research, 32(4), 359-368.

Scott, R. P., Davison, M. L. (1992). Religious Bias in Moral Development Research: A Psychometric Investigation. Journal for the Scientific Study of Religion, 31(4), 467-485.

Schwepker, C. H. (1999). Understanding Salespeople's Intention to Behave Unethically: The Effects of Perceived Competitive Intensity, Cognitive Moral Development and Moral Judgment. Journal of Business Ethics, 21(4), 303-316.

Swenson-Lepper, T. (2005). Ethical Sensitivity for Organizational Communication Issues: Examining Individual and Organizational Differences. Journal of Business Ethics, 59, 205-231. DOI 10.1007/s10551-005-2925-y.

Tatum, J. L., Foubert, J. D., Fuqua, D. R., Ray, C. M. (2013). The Relationship between First Year College Men's Religious Affiliation and Their Moral Development. College Student Affairs Journal, 31(2), 101-110.

Traiser, S., Eighmy, M. A. (2011). Moral Development and Narcissism of Private and Public University Business Students. Journal of Business Ethics, 99(3), 325-334.

Trevino, L. K. (1986), Ethical Decision Making in Organizations: A Person-Situation Interactionist Model. The Academy of Management Review, 11(3), 601-617. 
Trevino, L. K. (1992). Moral Reasoning and Business Ethics: Implications for Research, Education, and Management. Journal of Business Ethics, 11(5-6), 445-459.

Weber, J., Wasieleski, D. (2001). Investigating Influences on Managers' Moral Reasoning. The Impact of Context and Personal and Organizational Factors. Business \& Society, 40(1), 79-110. 